\title{
ARE THE MARGINAL CONVERGENCE OUTCOMES OF THE COHESION POLICY DIMINISHING?
}

\author{
Mindaugas BUTKUS ®1, Alma MAČIULYTE்-ŠNIUKIENE ${ }^{2 *}$, \\ Kristina MATUZEVIČIÜTE் ${ }^{3}$ \\ ${ }^{1,3}$ Department of Economics Engineering Faculty of Business Management, \\ Vilnius Gediminas Technical University, Vilnius, Lithuania \\ ${ }^{2}$ Department of Business Technology and Entrepreneurship, Faculty of Business Management, \\ Vilnius Gediminas Technical University, Vilnius, Lithuania
}

Received 13 January 2020; accepted 30 March 2020

\begin{abstract}
Significant disparities still exist between regions of the European Union, even though substantial Cohesion investments are directed to address this issue. To adjust the Cohesion Policy (CP), researchers assess the returns of the CP, but almost all studies are carried out at NUTS1\&2 or a country level, even though significant disparities occur at NUTS3 level. Moreover, just a few studies examine the non-linear effects of the CP, and none of them covers the NUTS3 disaggregation level. Filling the gap of previous contributions, the paper aims to investigate convergence outcomes of the CP at NUTS2\&3 level and to identify whether the marginal effect of the CP is diminishing. The estimation strategy is based on the modified specification of the difference-in-differences estimator that has an advantage while examining policy effects, using non-experimental data. Based on research findings, the essential guidelines for the improvement of the $\mathrm{CP}$ can be drawn up: i) the distribution policy of Cohesion investments should focus on smaller territorial units to reduce disparities at NUTS3 level; ii) the intensity of the CP's transfers has to be optimised because excessive intensity does not provide a positive return.
\end{abstract}

Keywords: Cohesion Policy, Cohesion investments, regional disparities, convergence, diminishing return, NUTS2, NUTS3.

JEL Classification: O47, O52, R11, R12, R15, R58.

\section{Introduction}

One of the issues of the European Union (EU) is the disparities between and within Member States (MS). The European Commission (EC) is addressing this issue by shaping CP and the allocation of the support from European Regional Development (ERDF) and Cohesion Funds (CF). One of the ultimate goals of CP's investments is to strengthen economic

${ }^{\star}$ Corresponding author. E-mail: alma.maciulyte-sniukiene@vgtu.lt 
and social cohesion by correcting imbalances between EU regions. Given the importance of CP's goals, great attention was paid in previous research to examine how successfully CP implemented these goals. However, the scientific studies most often investigate the impact of the CP on economic growth at countries, NUTS1\&2 disaggregation level and leave open the question what are the convergence outcomes of the CP and especially at NUTS3 level.

Most of the previous studies (Becker, 2012; Becker et al., 2015, 2018; Pellegrini et al., 2013; Maynou et al., 2016; Gagliardi \& Percoco, 2017; Di Cataldo, 2017; Piętak, 2018; Cerqua \& Pellegrini, 2018; Bourdin, 2019; Butkus et al., 2019; Berkowitz et al., 2020; Crescenzi \& Giua, 2020; among others) analyse linear relationship between economic growth and CP transfers, just a few studies (Wostner \& Šlander, 2009; Becker et al., 2012; Kyriacou \& RocaSagales, 2012; Pinho et al., 2015a; Pellegrini \& Cerqua, 2016; Pontarollo, 2017; Cerqua \& Pellegrini, 2018; Di Cataldo \& Monastiriotis, 2020) assessed non-linear outcomes of CP's investments. The results of these studies allow us to conclude that after a certain level of CP investments' intensity, additional investments do not generate significant positive outcomes. The analysis of previous studies has highlighted, that sources of non-linear relationship are related to moral hazard, substitution effects and diminishing return. These effects might lead to inefficient use of regional support.

Some authors identified an "optimal" level of CP investments' intensity but their studies cover NUTS1\&2 or country disaggregation, leaving the question what is the "optimal" level of the intensity at NUTS3 disaggregation level in terms of the impact on regional disparities. To address this gap, the paper aims to evaluate non-linear convergence outcomes of the CP at NUTS2\&3 disaggregation level and to provide main guidelines for the adjustment of the EU's CP. This research supplements previous contributions by identifying an "optimal" level of CP investments' intensity for positive marginal convergence outcomes at NUTS2\&3 disaggregation level.

The methodology is based on a difference-in-differences (DiD) approach to test empirically non-linear convergence effects of the EU's regional support at NUTS 3 level over the 2000-2006 and 2007-2013 programming periods.

The rest of the paper is organized as follows: Section 1 presents a literature review focusing on the non-linear relationship between CP and its outcomes. Section 2 describes the model based on difference-in-differences estimator to estimate the conditional marginal convergence outcomes of the CP. Section 3 presents and discusses the results of the estimations and provides possible directions for the improvement of the CP. The last section concludes the paper.

\section{Literature review on the non-linear relationship between the Cohesion Policy and its outcomes}

Analysis of previous research (Becker, 2012; Pellegrini et al., 2013; Becker et al., 2015, 2018; Maynou et al., 2016; Eberle \& Brenner, 2016; Gagliardi \& Percoco, 2017; Di Cataldo, 2017; Cerqua \& Pellegrini, 2018; Piętak, 2018; Bourdin, 2019; Berkowitz et al., 2020; Crescenzi \& Giua, 2020, etc.) reveals that most of the studies consider the linear relationship between $\mathrm{CP}$ and its outcomes, i.e. that the marginal effect of the CP is constant (unconditional). Au- 
thors confirm the positive and significant impact of regional support on economic growth or convergence. However, it should be noted that research also provides evidence on the heterogeneity of the $\mathrm{CP}$ outcomes, which might be related to diminishing return, substitution effect and moral hazard phenomenon (see Table 1). These effects may impose a non-linear (in the form of inverted U-shaped letter) relationship between CP investments' intensity and its outcomes, i.e. that marginal effect of the $\mathrm{CP}$ is not constant (conditional).

Table 1. Justification of non-linear relationship between CP and its outcomes (source: author's construction based on analysed literature)

\begin{tabular}{|c|c|c|}
\hline Effect & Explanation & Source \\
\hline $\begin{array}{l}\text { Diminishing } \\
\text { return }\end{array}$ & $\begin{array}{l}\text { Concept of diminishing return states that additional } \\
\text { investments in one of the production factors, when the } \\
\text { amount of other factors remains constant, decrease the } \\
\text { marginal output of the production. Since CP is mainly } \\
\text { directed towards investment projects, ERDF and CF transfers } \\
\text { may generate diminishing returns, i.e. the additional amount } \\
\text { of transfers to investment projects is expected to associate } \\
\text { with lower marginal outcomes. Therefore, it is assumed that } \\
\text { when CP investments' intensity reaches the threshold level, } \\
\text { additional investments do not generate positive marginal } \\
\text { productivity in the region and thus, GDP per capita growth } \\
\text { and convergence. Moreover, the marginal effect of the CP } \\
\text { might become negative. }\end{array}$ & $\begin{array}{l}\text { Wallace et al. } \\
(2010), \text { Becker } \\
(2012), \text { Becker } \\
\text { et al. (2012, 2015, } \\
\text { 2018), Gorzelak } \\
\text { (2016), European } \\
\text { Commission (2016) }\end{array}$ \\
\hline $\begin{array}{l}\text { Substitution } \\
\text { effect }\end{array}$ & $\begin{array}{l}\text { This effect occurs when beneficiary regions reduce their local } \\
\text { and/or national resources and substitute them with CP's } \\
\text { investments. Those public support schemes are inefficient and } \\
\text { are accompanied by such undesirable results: i) if projects } \\
\text { funded by ERDF and/or CF are close substitute for private } \\
\text { capital, this may have the effect of crowding out private } \\
\text { investment; ii) public entities would have to invest even } \\
\text { more if/when ERDF and CF support will end; iii) ERDF and } \\
\text { CF support loses its importance and without multiplicative } \\
\text { investments becomes unnecessary in lagging regions; iv) local } \\
\text { authorities lose motivation to generate enough revenue from } \\
\text { their own source; v) the usage of ERDF and CF transfers as a } \\
\text { substitute of local or national funds may reduce the potential } \\
\text { returns of CP enlisting inputs from more productive areas. }\end{array}$ & $\begin{array}{l}\text { Ederveen et al. } \\
\text { (2003), Beugelsdijk } \\
\text { and Eijffinger } \\
\text { (2005), Cibulskiene } \\
\text { and Butkus (2007), } \\
\text { Barca (2009), Del } \\
\text { Bo et al. (2016), } \\
\text { Marzinotto (2012), } \\
\text { Szitásiová et al. } \\
\text { (2014), European } \\
\text { Commission (2016) }\end{array}$ \\
\hline $\begin{array}{l}\text { Moral hazard } \\
\text { phenomenon }\end{array}$ & $\begin{array}{l}\text { This phenomenon is related to the considered parties' } \\
\text { aspirations to obtain additional benefits taking higher risks } \\
\text { and often violating established rules. As regions receive ERDF } \\
\text { and CF support only below a certain level of development, to } \\
\text { achieve or preserve beneficiary status, the regional or national } \\
\text { government may manipulate statistics. It can lead to funding } \\
\text { cut-off from productive projects and result in lower or even } \\
\text { negative outcomes of the CP. The rate of convergence between } \\
\text { regions may decrease or even increase regional divergence if } \\
\text { ERDF and/or CF transfers are directed to regions that have } \\
\text { already reached a high level of development. Corruption in } \\
\text { support allocation schemes is also related to a moral hazard } \\
\text { phenomenon and can lead to the same results. }\end{array}$ & $\begin{array}{l}\text { Beugelsdijk and } \\
\text { Eijffinger (2005) }\end{array}$ \\
\hline
\end{tabular}


Diminishing returns, substitution effects and moral hazard phenomenon justify the importance to determine the "optimal" intensity level of ERDF and CF transfers. Determining the "optimal" intensity level would allow a more rational redistribution of CP funds and make CP more effective. However, just a few previous studies (Mohl \& Hagen, 2008; Wostner \& Šlander, 2009; Becker et al., 2012; Kyriacou \& Roca-Sagales, 2012; Pinho et al., 2015a; Pellegrini \& Ceruqua, 2016; Pontarollo, 2017; Cerqua \& Pellegrini, 2018; Di Cataldo \& Monastiriotis, 2020) investigated potentially diminishing marginal outcomes of the CP. They all (except Mohl \& Hagen, 2008) have revealed that after a certain level of ERDF and/ or CF commitments' intensity, additional payments do not generate significant positive outcomes. Mohl and Hagen (2008) revealed that CP's transfers do not affect economic growth rate significantly and, considering this, conclude that it does not matter which "dose" of CP's transfers regions have received.

Becker et al. (2012) identified that beyond approximately 1.3 per cent of regional GDP, additional ERDF and CF transfers do not promote economic growth and the optimal desirable level of ERDF and CF transfer's intensity is 0.4 per cent of regional GDP. Pontarollo (2017) investigated non-linear relation between CP's transfers decomposed by intervention area (productive environment, human capital and infrastructure) and productivity as well as economic growth. The assessment results revealed that when the intensity of transfers exceeds $0.15-0.70$ per cent of regional GDP (depending on the intervention area), the marginal effect of transfers becomes negative. According to Pinho's et al. (2015a) findings, this boundary line is 3 per cent of countries GDP. According to Cerqua and Pellegrini's (2018) estimations, the outcomes of CP's transfers become statistically negligible and negative when intensity exceeds 305-350 Euro per capita. Di Cataldo and Monastiriotis (2020) have confirmed the hypothesis of diminishing returns of EU Funds in the UK case. Authors conclude that none of the regions in the UK exceeds the maximum desirable intensity threshold estimated by Cerqua and Pellegrini (2018).

It should be noted that Becker et al. (2012) expected to find a minimum diserble level of ERDF and CP transfer intensity below which transfers would not generate positive growth effect but above witch they would. However, the evaluation results rejected this assumption and the authors conclude that there is no evidence for exsistence of a minimum diserable level of regional transfers.

Bandonio and Pellegrini (2016), European Commission (2016), Pellegrini and Cergua (2016) agree that ERDF and CF transfers' intensity matters for returns, but do not highlight a desirable level. Also, it should be noted that previous studies do not determine the desirable level of ERDF and CF transfer's intensity at NUTS3 level and for positive impact on convergence.

\section{Methodology and data}

Most of the papers that deal with the outcomes of the CP adopt the model of conditional beta-convergence. This model allows to estimate the linear and non-linear effect of the CP on growth directly since the average growth rate is used as a dependent variable. Aiming to estimate the relation between transfers' intensity and disparities among EU regions, we can 
not rely on the same approach. Our model is grounded on a difference-in-differences (DiD) approach. The initial specification of the linear regression equation, which allows to estimate unconditional DiD parameter, is:

$$
Y_{i, t}=b_{0}+b_{1} \times t 2_{t}+b_{2} \times C P_{i, t}+b_{D i D} \times t 2_{t} \times C P_{i, t}+\varepsilon_{i, t},
$$

where $Y_{i, t}$ is the variable in the $i$-th region whose disparities between CP's beneficiaries and developed regions are under examination. $b_{0}$ is the estimated average $Y_{i, t}$ in the group of developed regions over the reference period. $t 2_{t}$ is a dummy variable equal to 1 for the $\mathrm{CP}$ intervention period and equal to 0 for the reference period. $b_{1}$ shows how the average $Y_{i, t}$ in the group of developed regions changed over the $\mathrm{CP}$ intervention period, compared with the reference period, i.e. how variable under consideration has changed without $\mathrm{CP}$ intervention. $C P_{i, t}$ is a dummy variable equal to 1 if the region received CP's transfers and 0 otherwise. $b_{2}$ shows how the average $Y_{i t}$ differed between CP's beneficiaries and developed regions already before the $\mathrm{CP}$ took place, i.e. shows the initial (over the reference period) difference between CP's beneficiaries and developed areas. The parameter on $b_{2}$ is expected to be negative since $\mathrm{CP}$ focuses on less developed areas. $b_{D i D}$ is the DiD parameter which shows the effect of the $\mathrm{CP}$, i.e. whether the initial negative differences between $\mathrm{CP}$ beneficiaries and developed regions became smaller due to the $C P$. Positive parameter on $b_{D i D}$ would give evidence that initial differences over the reference period became smaller over CP's intervention period, i.e. CP's transfers contributed to diminishing regional disparities. $\varepsilon_{i, t}$ is the error term.

Research assumes that regions will not respond to CP's transfers in the same way simply because the amount of transfers is not constant across regions. To put in other words, the effect of the CP hinges on the amount of transfers. Thus, some heterogeneity in the impact across regions is expected as well. It is possible to estimate DiD, assuming heterogeneity of the CP's effect by interacting $C P_{i, t}$ dummy with the intensity of CP's transfers, $I C P_{i, t}$. If a region does not receive $C P$ 's transfers, $C P_{i, t}$ and $I C P_{i, t}$ as well as their interaction equal to zero. If a region receives $C P$ 's transfers, $C P_{i, t}$ is equal to unity and its interaction with $I C P_{i, t}$ is equal to $I C P_{i, t}$. Thus, $C P_{i, t}$ substituting with $I C P_{i, t}$ will allow to estimate the effect of transfers' intensity on the disparities among regions:

$$
Y_{i, t}=b_{0}+b_{1} \times t 2_{t}+b_{2} \times I C P_{i, t}+b_{D i D} \times t 2_{t} \times I C P_{i, t}+\varepsilon_{i, t},
$$

where $b_{D i D}$ now measures the effect of $\mathrm{CP}$ transfers' intensity change by one unit on regional disparities.

To relax an assumption that the marginal effect of $I C P_{i, t}$ on the disparities is constant, i.e. the relationship is linear, and aiming to estimate the maximum desirable intensity level of CP's transfers, which still has a positive effect, and a minimal level of intensity that starts to have a significant impact, quadratic specification is introduced. To account for other factors affecting $Y_{i, t}, C_{j, i, t}$ that corresponds to a vector of time-varying factors, and $\theta_{i}$ that corresponds to a vector of time-constant factors are added:

$$
\begin{aligned}
& Y_{i, t}=b_{0}+b_{1} \times t 2_{t}+b_{21} \times I C P_{i, t}+b_{22} \times I C P_{i, t}^{2}+b_{D i D 1} \times \\
& t 2_{t} \times I C P_{i t}+b_{D i D 2} \times t 2_{t} \times I C P_{i, t}^{2}+c_{j} \times C_{j, i, t}+\mu \times \theta_{i}+\varepsilon_{i, t} .
\end{aligned}
$$


Positive $b_{D i D 1}$ and negative $b_{D i D 2}$ would give evidence of a quadratic form of relationship in the form of an inverted U. In the case of interactive Eqs (1) and (2), after the first differencing or time-demeaned transformations ${ }^{1}$, they collapse to simple additive models for the second (CP intervention) period, and estimated standard errors on coefficients associated with DiD parameter are unconditional. However, in the case of the Eq. (3) the multiplicative term is retained after the first differencing or time-demeaned transformations for the second $\operatorname{period}(t 2=1)$ :

$$
\begin{gathered}
\ddot{Y}_{i}=b_{0}+b_{1} \times(1)+b_{D i D 1} \times(1) \times I \ddot{C} P_{i}+b_{D i D 2} \times(1) \times I \ddot{C} P_{i}^{2}+c_{j} \times \ddot{C}_{j, i}+\varepsilon_{i} \\
\ddot{Y}_{i}=\left(b_{0}+b_{1}\right)+\left(b_{D i D 1}+b_{D i D 2} \times I \ddot{C} P_{i}\right) \times I \ddot{C} P_{i}+c_{j} \times \ddot{C}_{j, i}+\varepsilon_{i},
\end{gathered}
$$

where $\cdot$. stands for the time-demeaned variable ${ }^{2}$. Therefore, not only the marginal effect of $I C P_{i}$ on $Y_{i}$, i.e. the slope $\left(b_{D i D 1}+b_{D i D 2} \times I C P_{i}\right)$ is conditioned on the value of $I C P_{i}$ itself, but following Rodriguez-Pose and Garcilazo (2015) and Pinho et al. (2015b), it can be argued that the standard error of the estimated slope coefficient is also conditioned on $I C P_{i}$ value and standard error of the sum $\left(\hat{b}_{D i D 1}+\hat{b}_{D i D 2} \times I C P_{i}\right)$ is:

$$
S E_{\left(\hat{b}_{D i D 1}+\hat{b}_{D i D 2} \times I C P_{i}\right)}=\sqrt{\operatorname{var}\left(\hat{b}_{D i D 1}\right)+I C P_{i}^{2} \times \operatorname{var}\left(\hat{b}_{D i D 2}\right)+2 \times I C P_{i} \times \operatorname{cov}\left(\hat{b}_{D i D 1}, \hat{b}_{D i D 2}\right)} .
$$

This implies that the estimated marginal effect of $I C P_{i}$ on $Y_{i}$ can potentially be not significant over the all range of observed $I C P_{i}$ values, i.e. it is not necessary to reach the tipping point of $I C P_{i}$ the marginal effect not to differ from zero. In line with the usual logic of constructinr a coefficient a test of statistical significance against the possibility that the population rs zero, the t-value for the marginal effect of $I C P_{i}$ on $Y_{i}$ can be calculated, whadded to the equation, as:

$$
t=\frac{\hat{b}_{D i D 1}+\hat{\delta}_{D i D 2} \times I C P_{i}}{S E_{\left(\hat{b}_{D i D 1}+\hat{\delta}_{D i D 2} \times I C P_{i}\right)}}
$$

Having an empical relationship between $Y_{i}$ and $I C P_{i}$ in the form of inverted $\mathrm{U}$ letter, Eq. (6) enables us to test what the minimum level of $I C P_{i}$ is required for the marginal effect of $I C P_{i}$ on $Y_{i}$ to become significant and whether the marginal effect of $I C P_{i}$ is still significant when the tuing point is reached, and the marginal effect becomes negative.

Examination hodifferent intensity levels of CP transfers' intensity over the two last programming periods is related to diminishing regional disparities at NUTS2\&3 disaggregation

\footnotetext{
${ }_{1}^{1}$ These two alternative transformations are used to control all region-specific time-constant effects, i.e. $\theta_{i}$. For example, geographical position of the region, which determines its access to infrastructure, such as seaports, highways, etc. or economic linkages between regions, which can be an important growth factor for peripheral regions situated near the core regions. Having little possibility to control these effects by including all necessary variables at NUTS2\&3 disaggregation level, an unexplained variation which now would account for a part of the error term could lead to a correlation between $\varepsilon_{i, t}$ and $Y_{i, t}$ as well as between $\varepsilon_{i, t}$ and $I C P_{i, t}$. This correlation is very likely to occur since CP's transfers are not randomly distributed among regions, but depends on region's characteristics, which are also related to its growth and thus impose endogeneity problem.

${ }^{2}$ Using the first differencing, would yield quite the same equation, just $b_{0}$ would not be retained.
} 
is based on two databases. Compared to the study carried out concerning 2000-2006 programming period (SWECO, 2008), the report for 2007-2013 programming period (Ciffolilli et al., 2015) collects data on expenditure and not only allocations to selected projects. Having just allocations data for 2000-2006 period, but aiming to compare effects of two last fully expired programming periods, and considering that expenditure but not allocations could make an effect, few assumptions are put forward regarding policy intervention periods and calculation of CP transfers' intensity:

(i) Under the framework of the EU CP for 2000-2006 programming period, old MS could spend the last allocation available until the end of the year 2008 (the $n+2$ rule), and for the central and eastern European countries the rule was applied as $n+3$ of that time. From this perspective, 2000-2009 is considered as a CP intervention period for 2000-2006, since over 2000-2009 allocations could be spent and could make an effect. Financial support intensity is calculated as the ratio between allocations over 2000-2006 and total GDP over 2000-2009. 1995-1999 is considered as the reference period.

(ii) Since report for 2007-2013 programming period collected actual expenditure data by the end of 2014, 2007-2014 is considered as CP intervention period. Financial support intensity is calculated as the ratio between expenditures by the end of 2014 and the total GDP over 2007-2014. 2007, 2008 and 2009 overlap with the years over which the effect of the previous programming period is evaluated. The assumption here is that expenditures over 2007-2009 from the 2007-2013 programming period had no significant impact since the absorption capacity is increasing progressively when the end of the programming period is approaching. 2002-2006 is considered as the reference period.

For both periods, ERDF and CF allocations/expenditure combined are analysed. For 2000-2006 SWECO (2008) database contains data at NUTS2\&3 levels for the Cohesion Fund, ERDF Objective 1, ERDF Objective 2, URBAN and INTERREG IIIA allocations. The total amount mapped in the database for NUTS3 is 149.819 bill. EUR which is $93.5 \%$ and for NUTS2 is 156.174 bill. EUR which is $97.5 \%$ of the total CF and ERDF budget for the 2000-2006 programming period. All current EU MS except Bulgaria, Romania and Croatia could receive funding for the 2000-2006 programming period. Thus there were 1251 NUTS 3 and 260 NUTS2 level regions (according to NUTS classification that existed) under CP consideration. 188 NUTS 2 regions received funding and 72 did not. According to descriptive statistics, a minimum of transfers' intensity was $0.03 \%$, maximum $-2.92 \%$ with the average and median of $0.39 \%$ and $0.20 \%$, respectively. Over the same period, 871 NUTS 3 regions received funding a $380 \mathrm{did}$ not. According to descriptive statistics, a minimum of transfers' intensity was $0.01 \%$, maximum $-8.44 \%$ with the average and median of $0.37 \%$ and $0.13 \%$, respectively.

For the 2007-2013 programming period, Ciffolilli's et al. (2015) database contains cumulative expenditures of both ERDF and CF programmes at the NUTS2 (276) and 3 (1342) levels of EU reg f all 28 EU countries and covers the Convergence, Regional Competitiveness a Employment as well as the European Territorial Cooperation Objectives for the 2007-2013 programming period. The total amount mapped in the database for NUTS3 is 
200.193 bill. EUR which is $97.3 \%$ and for NUTS2 is 202.854 bill. EUR which is $98.6 \%$ of the total expenditures by the end of 2014. 191 NUTS2 regions received funding, and 85 did not. According to descriptive statistics, a minimum of transfers' intensity was $0.03 \%$, maximum $4.66 \%$ with the average and median of $0.72 \%$ and $0.34 \%$, respectively. Over the same period, 958 NUTS3 regions received funding, and 384 did not. According to descriptive statistics, a minimum of transfers' intensity was $0.02 \%$, maximum $-8.81 \%$ with the average and median of $0.63 \%$ and $0.15 \%$, respectively.

Table A1 (see Appendix) reports information on two variables considered in the research as the dependent since the aim is to estimate to what extent CP contributed to diminishing disparities among regions in terms of development level and productivity. Data on productivity over 1995-1999 is missing for Greece, except for Attiki, the Netherlands, and four UK regions. Data on Mayotte (France) is missing for all years. For Poland, the average was calculated including just two years, 1998 and 1999. Table A2 (see Appendix) reports information about control variables included in the model.

\section{Research results and discussion}

Tables 2 and 3 report fixed-effects estimates of Eq. (3) for two last programming periods. Estimations are made separately for a sample of NUTS2\&3 regions and two dependent variables - per capita GDP and productivity.

Table 2. Fixed effects estimates of 2000-2006 programming period

\begin{tabular}{|c|c|c|c|c|c|}
\hline \multirow{2}{*}{ Variable } & \multirow{2}{*}{ Parameter } & \multicolumn{2}{|c|}{ NUTS2 } & \multicolumn{2}{|c|}{ NUTS3 } \\
\hline & & $\ln \mathrm{GDP}^{(1)}$ & $\ln \mathrm{GVA}^{(2)}$ & $\ln \mathrm{GDP}^{(1)}$ & $\ln \mathrm{GVA}^{(2)}$ \\
\hline \multirow{2}{*}{ Intercept } & \multirow{2}{*}{$b_{0}$} & $9.81^{\star * \star}$ & $10.82^{\star * *}$ & $9.82^{\star \star \star}$ & $10.81^{\star \star \star}$ \\
\hline & & $(0.00)$ & $(0.01)$ & $(0.00)$ & $(0.00)$ \\
\hline \multirow{2}{*}{$t 2_{t}$} & \multirow{2}{*}{$b_{1}$} & $0.19^{* * *}$ & 0.02 & $0.17^{* * *}$ & 0.01 \\
\hline & & $(0.01)$ & $(0.01)$ & $(0.00)$ & $(0.01)$ \\
\hline \multirow{2}{*}{$t 2_{t} \times I C P_{i t}$} & \multirow{2}{*}{$b_{D i D 1}$} & $0.08^{\star *}$ & $0.17^{\star * *}$ & $0.04^{* * *}$ & $0.10^{\star * *}$ \\
\hline & & $(0.03)$ & $(0.05)$ & $(0.01)$ & $(0.02)$ \\
\hline \multirow{2}{*}{$t 2_{t} \times I C P_{i t}^{2}$} & \multirow{2}{*}{$b_{D i D 2}$} & $-0.04^{\star *}$ & -0.03 & -0.00 & $-0.01^{* * *}$ \\
\hline & & $(0.02)$ & $(0.03)$ & $(0.00)$ & $(0.00)$ \\
\hline \multirow{2}{*}{ IGDP } & \multirow{2}{*}{$c_{I G D P}$} & $0.01^{\star \star \star}$ & & & \\
\hline & & $(0.00)$ & & & \\
\hline \multirow{2}{*}{ ln IWORK } & \multirow{2}{*}{$c_{\text {IWORK }}$} & & $0.28^{\star * *}$ & & \\
\hline & & & $(0.10)$ & & \\
\hline \multirow{2}{*}{ PEDUC } & \multirow{2}{*}{$c_{\text {PEDUC }}$} & $-0.03^{* *}$ & $-0.03^{\star *}$ & & \\
\hline & & $(0.01)$ & $(0.01)$ & & \\
\hline \multirow{2}{*}{ TEDUC } & \multirow[b]{2}{*}{$c_{\text {TEDUC }}$} & 0.02 & $0.01^{\star}$ & & \\
\hline & & $(0.02)$ & $(0.02)$ & & \\
\hline
\end{tabular}


End of Table 2

\begin{tabular}{|c|c|c|c|c|c|}
\hline \multirow{2}{*}{ Variable } & \multirow{2}{*}{ Parameter } & \multicolumn{2}{|c|}{ NUTS2 } & \multicolumn{2}{|c|}{ NUTS3 } \\
\hline & & $\ln \mathrm{GDP}^{(1)}$ & $\ln \mathrm{GVA}^{(2)}$ & $\ln \mathrm{GDP}^{(1)}$ & $\ln \mathrm{GVA}^{(2)}$ \\
\hline \multirow{2}{*}{ HTEC } & \multirow{2}{*}{$c_{H T E C}$} & $0.00^{\star *}$ & & & \\
\hline & & $(0.00)$ & & & \\
\hline \multirow{2}{*}{ ln MINFR } & \multirow{2}{*}{$c_{M I N F R}$} & & 0.13 & & \\
\hline & & & $(0.10)$ & & \\
\hline \multirow{2}{*}{$\ln \mathrm{INOV}$} & \multirow{2}{*}{$c_{I N O V}$} & & $0.20^{\star * *}$ & & $0.16^{* * *}$ \\
\hline & & & $(0.08)$ & & $(0.06)$ \\
\hline \multirow{2}{*}{ ln PDENS } & \multirow{2}{*}{$c_{\text {PDENS }}$} & $0.15^{* *}$ & & $0.13^{\star *}$ & \\
\hline & & $(0.06)$ & & $(0.05)$ & \\
\hline \multirow{2}{*}{ PSTR } & \multirow[b]{2}{*}{$c_{P S T R}$} & 0.01 & & 0.01 & \\
\hline & & $(0.10)$ & & $(0.07)$ & \\
\hline \multirow{2}{*}{ AGVA } & \multirow{2}{*}{$c_{A G A V}$} & $-0.02^{\star *}$ & & $-0.03^{\star *}$ & \\
\hline & & $(0.00)$ & & $(0.00)$ & \\
\hline \multirow{2}{*}{ IGAV } & \multirow[b]{2}{*}{$c_{I G A V}$} & $0.01^{\star *}$ & & $0.01^{\star *}$ & \\
\hline & & $(0.00)$ & & $(0.00)$ & \\
\hline \multirow{2}{*}{ AEMPL } & \multirow[b]{2}{*}{$c_{A E M P L}$} & & $-0.03^{\star *}$ & & $-0.03^{\star \star}$ \\
\hline & & & $(0.00)$ & & $(0.00)$ \\
\hline \multirow{2}{*}{ IEMPL } & \multirow{2}{*}{$c_{I E M P L}$} & & $0.01^{\star *}$ & & $0.01^{\star \star}$ \\
\hline & & & $(0.00)$ & & $(0.00)$ \\
\hline \multicolumn{2}{|l|}{$\mathrm{N}$} & 520 & 466 & 2502 & 2326 \\
\hline \multicolumn{2}{|c|}{ Within R-squared } & 0.57 & 0.62 & 0.49 & 0.55 \\
\hline \multicolumn{2}{|c|}{ Estimated turning point, \% } & 1.08 & 2.69 & 5.95 & 3.99 \\
\hline
\end{tabular}

Notes: Robust (using HCCME) standard errors are presented in parentheses. ${ }^{*},{ }^{* *},{ }^{* * *}$ indicate statistical significance at the $10 \%, 5 \%$, and $1 \%$ levels, respectively. ${ }^{(1)} \ln$ GDP refers to estimates where logged regional per capita GDP is used as a dependent variable. ${ }^{(2)}$ ln GVA refers to estimates where logged regional GVA per worker is used as a dependent variable.

Table 3. Fixed effects estimates of 2007-2013 programming period

\begin{tabular}{|l|l|c|c|c|c|}
\hline \multirow{2}{*}{ Variable } & \multirow{2}{*}{ Parameter } & \multicolumn{2}{|c|}{ NUTS2 } & \multicolumn{2}{c|}{$\mathrm{NUTS}$} \\
\cline { 3 - 6 } & & $\ln \mathrm{GDP}^{(1)}$ & $\ln \mathrm{GVA}^{(2)}$ & $\ln \mathrm{GDP}^{(1)}$ & $\ln \mathrm{GVA}^{(2)}$ \\
\hline \multirow{2}{*}{ Intercept } & \multirow{2}{*}{$b_{0}$} & $9.92^{* * *}$ & $10.75^{* * *}$ & $9.88^{* * *}$ & $10.72^{* * *}$ \\
\cline { 3 - 6 } & & $(0.00)$ & $(0.00)$ & $(0.00)$ & $(0.00)$ \\
\hline \multirow{2}{*}{$t 2_{t}$} & $b_{1}$ & $0.03^{* * *}$ & $0.04^{* * *}$ & $0.04^{* * *}$ & $0.05^{* *}$ \\
\cline { 3 - 6 }$t 2_{t} \times I C P_{i t}$ & \multirow{2}{*}{$b_{D i D 1}$} & $(0.00)$ & $(0.01)$ & $(0.00)$ & $(0.00)$ \\
\hline \multirow{2}{*}{$t 2_{t} \times I C P_{i t}^{2}$} & \multirow{2}{*}{$b_{D i D 2}$} & $0.10^{* * *}$ & $0.10^{* * *}$ & $0.08^{* * *}$ & $0.05^{* * *}$ \\
\cline { 3 - 6 } & & $(0.02)$ & $(0.01)$ & $(0.01)$ & $(0.01)$ \\
\cline { 3 - 6 } & & $-0.02^{* * *}$ & $-0.03^{* * *}$ & $-0.01^{* * *}$ & $-0.01^{* * *}$ \\
\hline
\end{tabular}


End of Table 3

\begin{tabular}{|c|c|c|c|c|c|}
\hline \multirow{2}{*}{ Variable } & \multirow{2}{*}{ Parameter } & \multicolumn{2}{|c|}{ NUTS2 } & \multicolumn{2}{|c|}{ NUTS3 } \\
\hline & & $\ln \mathrm{GDP}^{(1)}$ & $\ln \mathrm{GVA}^{(2)}$ & $\ln \mathrm{GDP}^{(1)}$ & $\ln \mathrm{GVA}^{(2)}$ \\
\hline \multirow{2}{*}{ IGDP } & \multirow{2}{*}{$c_{I G D P}$} & $0.01^{\star * *}$ & & & \\
\hline & & $(0.00)$ & & & \\
\hline \multirow{2}{*}{ ln IWORK } & \multirow{2}{*}{$c_{\text {IWORK }}$} & & $0.23^{* * *}$ & & \\
\hline & & & $(0.07)$ & & \\
\hline \multirow{2}{*}{ PEDUC } & \multirow{2}{*}{$c_{\text {PEDUC }}$} & $-0.02^{\star \star \star}$ & $-0.01^{\star \star \star}$ & & \\
\hline & & $(0.00)$ & $(0.00)$ & & \\
\hline \multirow{2}{*}{ TEDUC } & \multirow{2}{*}{$c_{\text {TEDUC }}$} & $0.02^{*}$ & $0.02^{*}$ & & \\
\hline & & $(0.01)$ & $(0.01)$ & & \\
\hline \multirow{2}{*}{ HTEC } & \multirow{2}{*}{$c_{H T E C}$} & $0.00^{* *}$ & & & \\
\hline & & $(0.00)$ & & & \\
\hline \multirow{2}{*}{ ln MINFR } & \multirow{2}{*}{$c_{\text {MINFR }}$} & & 0.15 & & \\
\hline & & & $(0.12)$ & & \\
\hline \multirow{2}{*}{ In INOV } & \multirow[b]{2}{*}{$c_{I N O V}$} & & $0.19^{\star \star \star}$ & & $0.18^{* * *}$ \\
\hline & & & $(0.06)$ & & $(0.05)$ \\
\hline \multirow{2}{*}{ In PDENS } & \multirow[b]{2}{*}{$c_{\text {PDENS }}$} & $0.16^{* *}$ & & $0.15^{\text {** }}$ & \\
\hline & & $(0.07)$ & & $(0.06)$ & \\
\hline \multirow{2}{*}{ PSTR } & \multirow{2}{*}{$c_{P S T R}$} & 0.02 & & 0.02 & \\
\hline & & $(0.08)$ & & $(0.05)$ & \\
\hline \multirow{2}{*}{ AGVA } & \multirow{2}{*}{$c_{A G A V}$} & $-0.02^{\star *}$ & & $-0.03^{\star *}$ & \\
\hline & & $(0.00)$ & & $(0.00)$ & \\
\hline \multirow{2}{*}{ IGAV } & \multirow{2}{*}{$c_{I G A V}$} & $0.01^{* *}$ & & $0.01^{\star *}$ & \\
\hline & & $(0.00)$ & & $(0.00)$ & \\
\hline \multirow{2}{*}{ AEMPL } & \multirow{2}{*}{$c_{A E M P L}$} & & $-0.03^{\star *}$ & & $-0.03^{\star *}$ \\
\hline & & & $(0.00)$ & & $(0.00)$ \\
\hline \multirow{2}{*}{ IEMPL } & \multirow{2}{*}{$c_{I E M P L}$} & & $0.01^{\star *}$ & & $0.01^{\star *}$ \\
\hline & & & $(0.00)$ & & $(0.00)$ \\
\hline \multicolumn{2}{|l|}{$\mathrm{N}$} & 552 & 550 & 2684 & 2682 \\
\hline Within R-sq & & 0.57 & 0.51 & 0.59 & 0.40 \\
\hline Estimated tu & ng point, \% & 1.08 & 2.20 & 1.84 & 3.07 \\
\hline
\end{tabular}

Notes: Robust (using HCCME) standard errors are presented in parentheses. ${ }^{*}, * *,{ }^{* * *}$ indicate statistical significance at the $10 \%, 5 \%$, and $1 \%$ levels, respectively. ${ }^{(1)} \ln$ GDP refers to estimates where logged regional per capita GDP is used as a dependent variable. ${ }^{(2)}$ ln GVA refers to estimates where logged regional GVA per worker is used as a dependent variable.

The estimated direction of the effect on control variables seems to be reasonable. Higher investment ratio, a more significant share of employed in high-technology sectors, higher population density and thus agglomeration effect, bigger industry sector according to a share of created GVA have a positive and statistically significant effect on regional per capita GDP. A bigger proportion of the working-age population and share of it with tertiary education 
seems to have a positive but insignificant effect on per capita GDP in a region. On the contrary, a more significant proportion of the working-age population with primary education and size of the agriculture sector in a region is negatively and significantly related to its per capita GDP. Amount of investment per worker, workers' tertiary education, innovations, and a higher share of empd in industry sector have a significant positive correlation, whereas primary education and employment in agriculture have a significant negative correlation with productivity. Infrastructure measured as the density of motorways has an insignificant positive effect.

All estimations show that CP contributed to diminishing disparities among regions in terms of their development level and productivity. Nevertheless, the relationship between funding intensity and the effect on disparities is non-linear, suggesting that not in all regions and not all support had a positive effect. The last row in Tables 2 and 3 reports the estimated turning point of CP transfer's intensity. The marginal effect of transfer's intensity above this point on diminishing disparities is estimated to be negative. Table A3 (see Appendix) reports which regions were overfunded according to estimated turning points in Tables 2 and 3. Calculations are made separately for both programming periods, taking into account disaggregation level and dependent variable under consideration.

Some differences are comparing two programming periods and two disaggregation levels. The overfunding was more typical for 2007-2013 programming period and NUTS 2 level (over both periods under investigation). Among mostly overfunded dominate regions from Portugal and Greece (over 2000-2006 programming period) and regions from Poland, Hungary, Bulgaria, Portugal and Greece (over 2007-2013 programming period). It seems that a vast amount of ERDF and CF funding for the least developed regions did not help to increase their productivity and development level significantly enough for convergence to occur.

Figures 1-4 present the following relationships: (i) between level of CP's transfers intensity and estimated effect on disparities; (ii) between level of CP's transfers intensity and estimated conditional effect on disparities; (iii) between level of CP's transfers intensity and

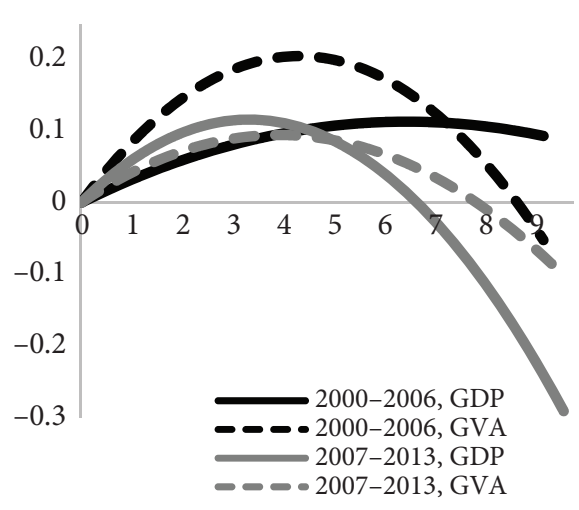

a) at NUTS 3 level

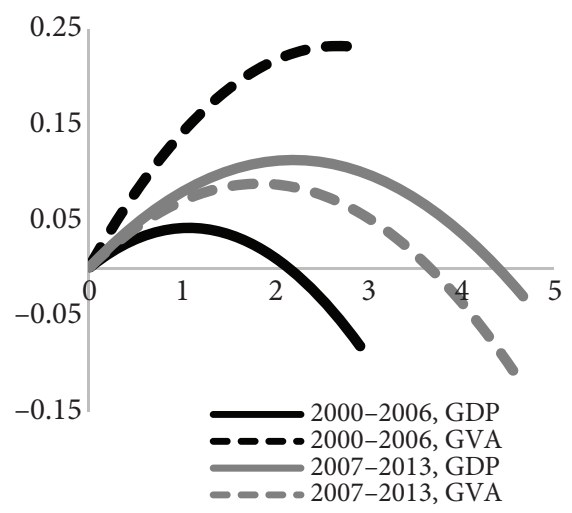

b) at NUTS 2 level

Figure 1 . The estimated effect of CP's transfers' intensity ( ICP, horizontal axis) on disparities $\left(b_{D i D 1} \times I C P_{i}+b_{D i D 2} \times I C P_{i}^{2}\right.$, vertical axis $)$ 
standard error of estimated conditional effect on disparities, and (iv) between level of CP's transfers intensity and t-ratio of estimated conditional effect on disparities, respectively. They allow to analyse not only the size but also the significance of the estimated effect.

According to estimation results, distribution of ERDF and CF transfers across regions over the last two programng periods was far from being an optimal, considering maximising the effect of ERDF anCF expenditures on diminishing disparities. The same is true for both disaggregation levels and both dependent variables under consideration. Although in a wide range of relatively high transfers' intensity levels its marginal positive (or negative) effect on disparities is estimated as statistically insignificant, in some extreme cases of transfers' intensity not only marginal but also total effect on convergence was significant and negative.

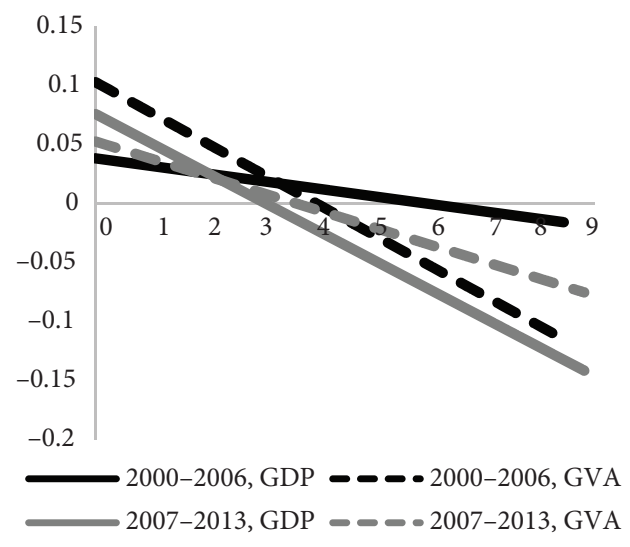

a) at NUTS 3 level

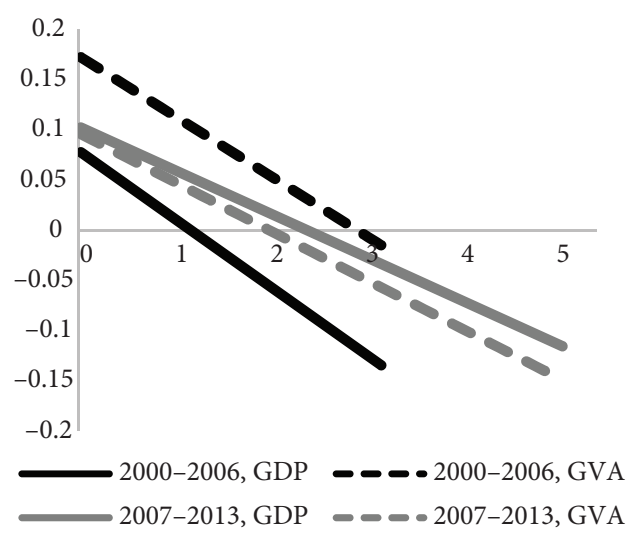

b) at NUTS 2 level

Figure 2. Estimated conditional effect, i.e. slope $\left(b_{D i D 1}+b_{D i D 2} \times I C P_{i}\right.$, vertical axis $)$ of CP transfers' intensity ( $I C P_{i}$, horizontal axis)

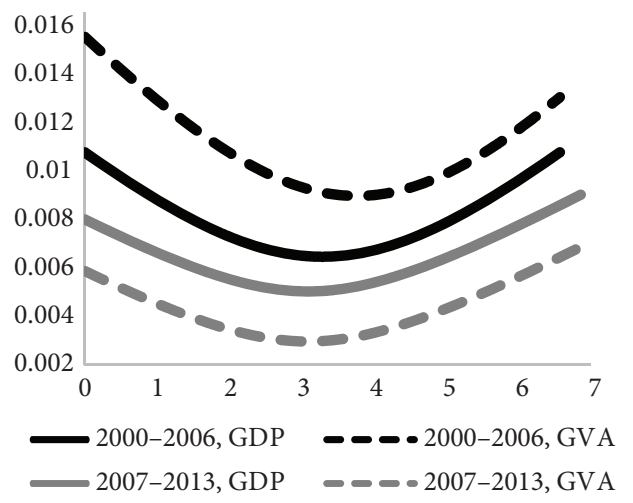

a) at NUTS 3 level

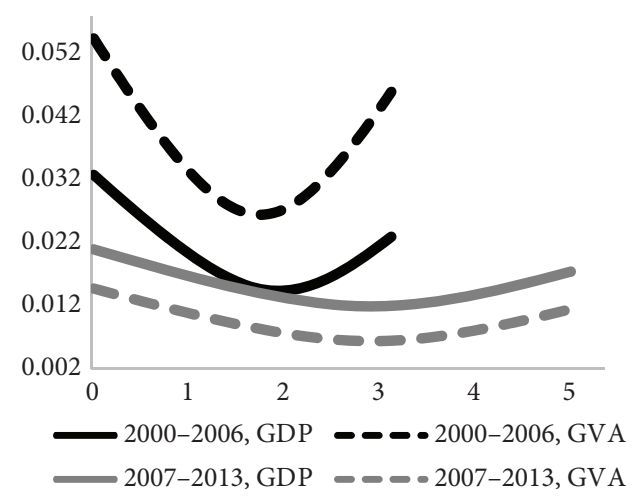

b) at NUTS 2 level

Figure 3. Relationship between CP transfers' intensity ( $I C P_{i}$, horizontal axis) and standard error (vertical axis) of estimated conditional effect $\left(b_{D i D 1}+b_{D i D 2} \times I C P_{i}\right.$, vertical axis) 


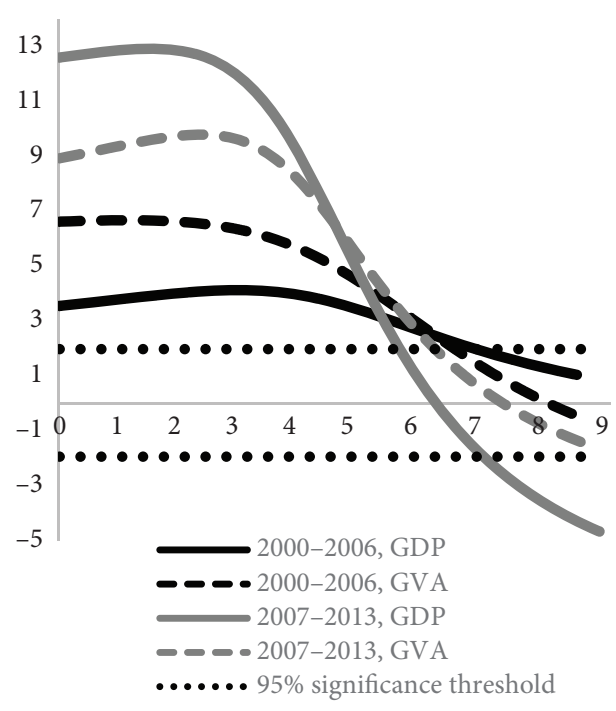

a) at NUTS 3 level

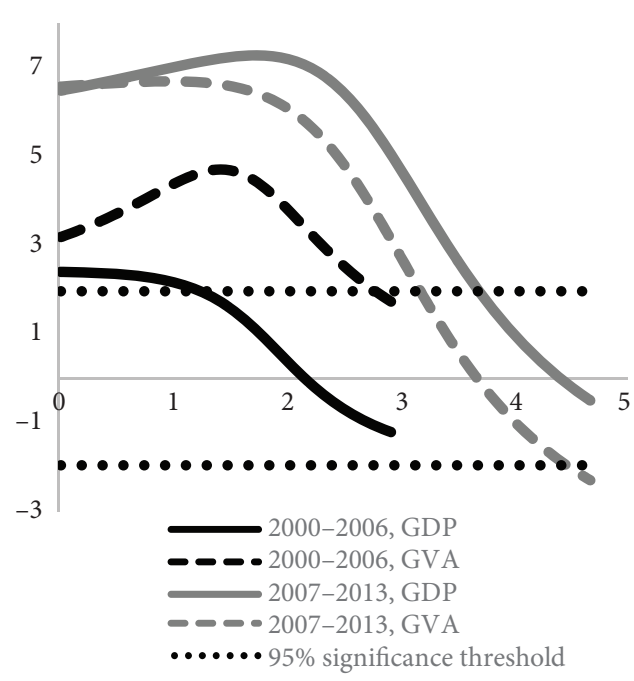

b) at NUTS 2 level

Figure 4. Relationship between CP transfers' intensity ( $I C P_{i}$, horizontal axis) and t-ratio (vertical axis) of estimated conditional effect $\left(b_{D i D 1}+b_{D i D 2} \times I C P_{i}\right)$

These results are in line with previous research analysing earlier programming periods and effect on other than convergence outcomes. Despite the fact that estimated turning points (the maximum desirable funding intensity) are higher compared to existing empirical evidence (probably due to different outcome variable, analysed period, and method), general conclusion is quite the same - there are too many too much funded regions, which are not spending ERDF and CF allocations efficiently to boost their productivity and growth to ensure regional convergence.

herefore, the re-allocation of ES funds, avoiding overfunding, is crucial over the following programming period to ensure more efficient use. This conclusion also brings us to one more question - what causes the inefficient use of SF and CF funding in highly supported regions? Is it a matter of a simple diminishing returns to investment or more complicated issue related to corruption, misallocation of funds due to shortage of managerial knowledge or week institutional environment? Having a robust answer to this question would allow to firstly direct funding to solve problems in the areas which interfere efficient use of regional support.

\section{Conclusions}

The previous contributions have left the question what is the "optimal" intensity level of the $\mathrm{CP}$ in terms of the impact on regional disparities and especially at NUTS3 disaggregation by covering exclusively NUTS1\&2 or country levels and analysing just growth. Our research which includes two last fully expired programming periods, i.e. 2000-2006 and 2007-2013, allowed to evaluate the "optimal" intensity level of CP investments that ensures positive marginal convergence outcomes at NUTS2\&3 disaggregation level. 
Results considering diminishing marginal outcomes of the CP are in line with previous research which focuses on earlier programming periods and the effect on other than convergence outcomes. Research shows higher turning points (the maximum desirable funding intensity) compared to previous contributions, and this could be due to different applied methodology, alternative CP outcome under consideration, and disaggregation level as well as more recent programming period that is covered in presented research.

Estimation results shed some light on the sources of the heterogeneous outcomes of the CP, i.e. why the effects of CP's investments vary across regions. This analysis also gives some insights on the inter-regional allocation of ERDF and CF: (i) there is a need to focus on smaller territorial units setting the aims and negotiating regarding allocation commitments in order to reduce disparities at NUTS3 disaggregation; ii) the intensity of the CP's investments has to be optimised since excessive intensity does not provide positive returns, thus setting the maximum allocations to GDP ratio and avoiding concentration of the investment in a few heavily underdeveloped regions would increase the overall effectiveness of the CP.

Our study has some limitations that could be addressed in future research. First, estimated turning points based on two last fully expired programming periods could change at some point when the data on ongoing 2014-2020 programming period will become available and will be included in the research. Nevertheless, planning allocations for the next, i.e. programming period of 2021-2027 it is essential to take into account which regions were previously overfunded avoiding same inefficiencies in the future. Second, our research assumes that the marginal effect of the $\mathrm{CP}$ on convergence is homogenous across regions. A growing body of literature on moderators of CP outcomes suggests that this could be not the case, and future research could concentrate on finding which factors may shift this turning point.

\section{Funding}

This work was supported by the Research Council of Lithuania under agreement No. SMIP-17-114.

\section{Acknowledgements}

This paper is based on the presentation "Regional Financial Support Policy: What we have Learned from the Past and where are we Moving" made at the International Conference on Regional Science, 20-22 November 2019, Castelo.

\section{Author contributions}

Conceptualization, AMS, MB and KM; methodology, MB.; data collection KM, theoretical analysis, AMS and KM., writing - original draft preparation, AMS, MB and KM. All authors contributed to the experiment design and have read and approved the final manuscript. 


\section{Disclosure statement}

We declare that we do not have any competing financial, professional, or personal interests from other parties.

\section{References}

Bandonio, D., \& Pellegrini, G. (2016). Macro-economic effects of cohesion policy funding's in 2007-2013. Executive Summary. European Commission. Publications Office of the European Union.

Barca, F. (2009). An agenda for a reformed cohesion policy: A place-based approach to meeting European Union challenges and expectations. http://www.europarl.europa.eu/meetdocs/2009_2014/documents/regi/dv/barca_report_/barca_report_en.pdf

Becker, S. O. (2012). EU structural funds: Do they generate more growth? (The CAGE-Chatham House, Series No. 3, December 2012). Chatham House.

Becker, S. O., Egger, P. H., \& von Ehrlich, M. (2018). Effects of EU regional policy: 1989-2013. Regional Science and Urban Economics, 69, 143-152. https://doi.org/10.1016/j.regsciurbeco.2017.12.001

Becker, S. O., Egger, P., \& von Ehrlich, M. (2012). Too much of a good thing? On the growth effects of the EU's regional policy. European Economic Review, 56, 648-668. https://doi.org./10.1016/j.euroecorev.2012.03.001

Becker, S. O., Egger, P., \& von Ehrlich, M. (2015). Regional policy. In H. Badinger, \& V. Nitsch (Eds.), Handbook of the economics of European integration (Chapter 17). Routledge.

Berkowitz, P., Monfort, P., \& Pieńkowski, J. (2020). Unpacking the growth impacts of European Union Cohesion Policy: Transmission channels from Cohesion Policy into economic growth. Regional Studies, 54(1), 60-71. https://doi.org/10.1080/00343404.2019.1570491

Beugelsdijk, M. S, \& Eijffinger, S. C. W. (2005). The effectiveness of structural policy in the European Union: An empirical analysis for the EU-15 in 1995-2001. Journal of Common Market Studies, 43, 37-51. https://doi.org/10.1111/j.0021-9886.2005.00545.x

Bourdin, S. (2019). Does the cohesion policy have the same influence on growth everywhere? A geographically weighted regression approach in Central and Eastern Europe. Economic Geography, 95(3), 256-287. https://doi.org/10.1080/00130095.2018.1526074

Butkus, M., Mačiulytė-Šniukienè, A., Matuzevičiūtè, K., \& Cibulskienė, D. (2019). What is the return on investing European regional development and Cohesion funds? Difference-in-differences estimator approach. Ekonomický časopis, 67(6), 647-676.

Cerqua, A., \& Pellegrini, G. (2018). Are we spending too much to grow? The case of Structural Funds. Journal of Regional Science, 58, 535-563. https://doi.org/10.1111/jors.12365

Cibulskiene, D., \& Butkus, M. (2007). The influence of cumulative causation process on regional divergence in Lithuania during 1995-2003. Jahrbuch fur Regionalwissenschaft, 27(1), 59-87. https://doi.org/10.1007/s10037-006-0011-2

Ciffolilli, A., Condello, S., Pompili, M., \& Roemish, R. (2015). Geography of Expenditure. Final Report. Work Package 13. Ex post evaluation of Cohesion Policy programmes 2007-2013, focusing on the European Regional Development Fund (ERDF) and the Cohesion Fund (CF). https://ec.europa.eu/ regional_policy/sources/docgener/evaluation/pdf/expost2013/wp13_final_report_en.pdf

Crescenzi, R., \& Giua, M. (2020). One or many Cohesion Policies of the European Union? On the differential economic impacts of Cohesion Policy across member states. Regional Studies, 54(1), 10-20. https://doi.org/10.1080/00343404.2019.1665174 
Del Bo, C., Florio, M., Sirtori, E., \& Vignetti, S. (2016). Additionality and regional development: Are EU Structural Funds complements or substitutes of national Public Finance? https://doi.org/10.2139/ssrn.2723402

Di Cataldo, M. (2017). The impact of EU Objective 1 funds on regional development: Evidence from the UK and the prospect of Brexit. Journal of Regional Science, 57(5), 814-839. https://doi.org/10.1111/jors.12337

Di Cataldo, M., \& Monastiriotis, V. (2020). Regional needs, regional targeting and regional growth: an assessment of EU Cohesion Policy in UK regions. Regional Studies, 54(1), 35-47. https://doi.org/10.1080/00343404.2018.1498073

Eberle, J., \& Brenner, T. (2016). More bucks, more growth, more justice? The effects of regional structural funds on regional economic growth and convergence in Germany (Working Papers on Innovation and Space, 01.16). Philipps University Marburg, Department of Geography, Marburg. Retrieved October 26, 2018, from http://hdl.handle.net/10419/147971

Ederveen, S., Gorter, J., de Mooij, R., \& Nahuis, R. (2003). Funds and Games: The Economics of European Cohesion Policy (Occasional Papers 03). European Network of Economic Policy Research Institutes. http://aei.pitt.edu/1965/

European Commission. (2016). Measuring the impact of Structural and Cohesion Funds using regression discontinuity design in EU27 in the period 1994-2011, Ex post evaluation of Cohesion Policy programmes 2007-2013, focusing on the European Regional Development Fund (ERDF) and the Cohesion Fund (CF) (Final technical Report, Work Package 14c - Tasks 2 and 3).

Gagliardi, L., \& Percoco, M. (2017). The impact of European Cohesion Policy in urban and rural regions. Regional Studies, 51(6), 857-868. https://doi.org/10.1080/00343404.2016.1179384

Gorzelak, G. (2016). Cohesion Policy and regional development. In J. Bachtler, P. Berkowitz, S. Hardy, \& T. Muravska (Eds.), 33EU Cohesion Policy - Reassessing performance and direction. Routledge.

Kyriacou, A. P., \& Roca-Sagales, O. (2012). The impact of EU structural funds on regional disparities within member states. Environment and Planning C: Politics and Space, 30(2), 267-281. https://doi.org.10.1068/c11140r

Marzinotto, B. (2012). The growth effects of EU cohesion policy: A meta-analysis (Bruegel working paper No. 2012/14). Bruegel, Brussels. https://www.econstor.eu/bitstream/10419/78011/1/728570688.pdf

Maynou, L., Saez, M., Kyriacou, A., \& Bacaria, J. (2016). The impact of structural and Cohesion Funds on Eurozone convergence, 1990-2010. Regional Studies, 50(7), 1127-1139. https://doi.org/10.1080/00343404.2014.965137

Mohl, P., \& Hagen, T. (2008). Does EU cohesion policy promote growth? Evidence from regional data and alternative econometric approaches (ZEW Discussion Paper 08-086). https://doi.org/10.2139/ssrn.1298935

Pellegrini, G., \& Cerqua, A. (2016, October 20-22). Measuring the impact of intensity of treatment using RDD and covariates: The case of Structural Funds [Conference presentation]. 57 ${ }^{\text {th }}$ RSA Annual Conference, Bocconi University, Milan, Italy.

Pellegrini, G., Terribile, F., Tarola, O., Muccigrosso, T., \& Busillo, F. (2013). Measuring the effects of European Regional Policy on economic growth: A regression discontinuity approach. Papers in Regional Science, 92(1), 217-233. https://doi.org/10.1111/j.1435-5957.2012.00459.x

Piętak, L. (2018). Did structural funds affect economic growth and convergence across regions? Spanish case in the years 1989-2016 (INE PAN Working Paper Series, No. 44). http://inepan.pl/wp-content/ uploads/2016/07/working-papers-44-Hiszpania-Pietak.pdf

Pinho, C., Varum, C., \& Antunes, M. (2015a). Structural funds and European regional growth: Comparison of effects among different programming periods. European Planning Studies, 23(7), 1302-1326. https://doi.org/10.1080/09654313.2014.928674 
Pinho, C., Varum, C., \& Antunes, M. (2015b). Under what conditions do structural funds play a significant role in European regional economic growth? Some evidence from recent panel data. Journal of Economic Issues, 49(3), 749-771. https://doi.org/10.1080/00213624.2015.1072382

Pontarollo, N. (2017). Does Cohesion Policy affect regional growth? New evidence from a semi-parametric approach. In J. Bachtler, P. Berkowitz, S. Hardy, \& T. Muravska (Eds.), EU cohesion policy (pp. 93-108). Routledge.

Rodríguez-Pose, A., \& Garcilazo, E. (2015). Quality of government and the returns of investment: Examining the impact of Cohesion expenditure in European Regions. Regional Studies, 49, 1274-1290. https://doi.org/10.1080/00343404.2015.1007933

SWECO. (2008). Final Report - ERDF and CF Regional Expenditure Contract No. 2007.CE.16.0.AT.036. https://ec.europa.eu/regional_policy/sources/docgener/ evaluation/pdf/expost2006/ expenditure_final.pdf

Szitásiová, V., Martišková, M., \& Šipikal, M. (2014). Substitution effect of public support programs at local level. Transylvanian Review of Administrative Sciences, 10(SI), 167-182.

Wallace, H. S., Pollack, M. A., \& Young, A. R. (2010). Policy-making in the European Union. Oxford University Press.

Wostner, P., \& Šlander, S. (2009). The effectiveness of EU cohesion policy revisited: Are EU funds really additional? (European Policy Research Paper No. 69). European Policies Research Centre.

\section{APPENDIX}

Table A1. Dependent variables of the research

\begin{tabular}{|c|c|c|}
\hline Short name & Full name & Description and source of data \\
\hline GDP & $\begin{array}{l}\text { Regional per } \\
\text { capita GDP } \\
\text { at constant } \\
\text { prices }\end{array}$ & $\begin{array}{l}\text { The main source of the data is Gross domestic product indicators (reg_ } \\
\text { ecologdp), subsection for the Gross domestic product (GDP) at current } \\
\text { market prices by NUTS3 regions (nama_10r_3gdp). To correct the } \\
\text { changes at price levels over time, Price index (implicit deflator), } 2010 \\
\text { = 100, euro (PD10_EUR) is used. To calculate per capita GDP, Average } \\
\text { annual population to calculate regional GDP data (thousand persons) } \\
\text { by NUTS } 3 \text { regions (nama_10r_3popgdp) is used. Data for GDP and } \\
\text { population in the aforementioned Eurostat data sources are not } \\
\text { available prior to 2000. Data for } 1995-1999 \text { on Gross domestic product } \\
\text { (GDP) at current market prices at NUTS level } 3 \text { and Average annual } \\
\text { population was retrieved from nama_r_e3gdp and demo_r_d3avg } \\
\text { datasets, respectively, that were available on Eurostat previously and } \\
\text { merged with currently available dataset. }\end{array}$ \\
\hline GVA & $\begin{array}{l}\text { Regional } \\
\text { GVA per } \\
\text { employed } \\
\text { at constant } \\
\text { prices }\end{array}$ & $\begin{array}{l}\text { The main source of the data is Branch and household accounts (reg_ } \\
\text { eco10brch), subsection for Gross value added (GVA) at basic prices by } \\
\text { NUTS } 3 \text { regions (nama_10r_3gva). To correct the changes at price } \\
\text { levels over time, Price index (implicit deflator), 2010=100, euro (PD10_ } \\
\text { EUR) is used. To calculate GVA per worker, Employment (thousand } \\
\text { persons) by NUTS } 3 \text { regions (nama_10r_3empers) is used. Data for } \\
\text { GVA and employment in aforementioned Eurostat data sources is not } \\
\text { available prior to 2000. Data for 1995-1999 on Gross value added at } \\
\text { basic prices at NUTS level } 3 \text { and Employment (in persons) at NUTS } \\
\text { level } 3 \text { was retrieved from nama_r_e3vabp95 and nama_r_e3empl95 } \\
\text { datasets, respectively, that were available on Eurostat previously and } \\
\text { merged with currently available dataset. }\end{array}$ \\
\hline
\end{tabular}


Table A2. Control variables ${ }^{3}$ of the research

\begin{tabular}{|c|c|c|c|c|c|c|}
\hline \multirow{2}{*}{$\begin{array}{l}\text { Short } \\
\text { name }\end{array}$} & \multirow{2}{*}{$\begin{array}{l}\text { Full name, description and } \\
\text { source of data }\end{array}$} & \multirow{2}{*}{$\begin{array}{l}\text { Measure- } \\
\text { ment unit }\end{array}$} & \multicolumn{2}{|c|}{$\begin{array}{l}\text { NUTS level at which } \\
\text { data is available }\end{array}$} & \multicolumn{2}{|c|}{$\begin{array}{l}\text { Model for which } \\
\text { variable is used }\end{array}$} \\
\hline & & & 2 & 3 & GDP & GVA \\
\hline IGDP & $\begin{array}{l}\text { Investment calculated as the } \\
\text { ratio between Gross fixed capital } \\
\text { formation by NUTS } 2 \text { regions } \\
\text { (nama_10r_2gfcf) and Gross do- } \\
\text { mestic product (GDP) at current } \\
\text { market prices by NUTS } 2 \text { regions } \\
\text { (nama_10r_2gdp). }\end{array}$ & $\%$ & $\mathrm{X}$ & & $\mathrm{X}$ & \\
\hline IWRK & $\begin{array}{l}\text { Investment calculated per worker, } \\
\text { as the ratio between Gross fixed } \\
\text { capital formation by NUTS } \\
2 \text { regions (nama_10r_2gfcf) } \\
\text { and Employment (thousand } \\
\text { persons) by NUTS } 3 \text { regions } \\
\text { (nama_10r_3empers). }\end{array}$ & Eur. & $\mathrm{X}$ & & & $\mathrm{X}$ \\
\hline PEDUC & $\begin{array}{l}\text { Primary education, i.e. pro- } \\
\text { portion of population aged 25- } \\
64 \text { years with less than primary, } \\
\text { primary and lower secondary } \\
\text { education (levels 0-2). Data } \\
\text { retrieved from Population aged } \\
25-64 \text { by educational attainment } \\
\text { level, sex and NUTS } 2 \text { regions (\%) } \\
\text { (edat_lfse_04). }\end{array}$ & $\%$ & $\mathrm{X}$ & & $\mathrm{X}$ & $\mathrm{X}$ \\
\hline TEDUC & $\begin{array}{l}\text { Tertiary education, i.e. propor- } \\
\text { tion of population aged 25-64 } \\
\text { years - with tertiary education } \\
\text { (levels 5-8). Data retrieved } \\
\text { from Population aged } 25-64 \text { by } \\
\text { educational attainment level, sex } \\
\text { and NUTS } 2 \text { regions (\%) (edat_ } \\
\text { lfse_04). }\end{array}$ & $\%$ & $\mathrm{X}$ & & $\mathrm{X}$ & $\mathrm{X}$ \\
\hline HTEC & $\begin{array}{l}\text { Employment in High-technology } \\
\text { sectors (high-technology manu- } \\
\text { facturing and knowledge-intensive } \\
\text { high-technology services). Data } \\
\text { for 1995-2007 retrieved from } \\
\text { Employment in technology and } \\
\text { knowledge-intensive sectors by } \\
\text { NUTS } 2 \text { regions and sex (1994- } \\
2008, \text { NACE Rev. 1.1) (htec_- } \\
\text { emp_reg). For 2007-2017 from } \\
\text { Employment in technology and } \\
\text { knowledge-intensive sectors by } \\
\text { NUTS 2 regions and sex (from } \\
\text { 2008 onwards, NACE Rev. 2) } \\
\text { (htec_emp_reg2). }\end{array}$ & $\begin{array}{c}\text { Percentage } \\
\text { of total } \\
\text { employ- } \\
\text { ment }\end{array}$ & $\mathrm{X}$ & & $\mathrm{X}$ & \\
\hline
\end{tabular}

\footnotetext{
3 If the data for 1995-1999 according to The European System of National and Regional Accounts (ESA, 2010) was missing, it was collected according to ESA 1995 and merged with current dataset.
} 
Continued Table A2

\begin{tabular}{|c|c|c|c|c|c|c|}
\hline \multirow{2}{*}{$\begin{array}{l}\text { Short } \\
\text { name }\end{array}$} & \multirow{2}{*}{$\begin{array}{l}\text { Full name, description and } \\
\text { source of data }\end{array}$} & \multirow{2}{*}{$\begin{array}{l}\text { Measure- } \\
\text { ment unit }\end{array}$} & \multicolumn{2}{|c|}{$\begin{array}{l}\text { NUTS level at which } \\
\text { data is available }\end{array}$} & \multicolumn{2}{|c|}{$\begin{array}{l}\text { Model for which } \\
\text { variable is used }\end{array}$} \\
\hline & & & 2 & 3 & GDP & GVA \\
\hline MINFR & $\begin{array}{l}\text { Motorways. Retrieved from } \\
\text { Road, rail and navigable inland } \\
\text { waterways networks by NUTS } 2 \\
\text { regions (tran_r_net). }\end{array}$ & $\begin{array}{l}\text { Kilometres } \\
\text { of motor- } \\
\text { ways per } \\
\text { thousand } \\
\text { square } \\
\text { kilometres }\end{array}$ & $\mathrm{X}$ & & & $\mathrm{X}$ \\
\hline PDENS & $\begin{array}{l}\text { Population density by NUTS } 3 \\
\text { region (demo_r_d3dens). }\end{array}$ & $\begin{array}{l}\text { Inhabi- } \\
\text { tants per } \\
\text { square } \\
\text { kilometre }\end{array}$ & $\mathrm{X}$ & $\mathrm{X}$ & $\mathrm{X}$ & \\
\hline PSTR & $\begin{array}{l}\text { Population structure calculated } \\
\text { as proportion of population aged } \\
15-64 \text { years to total number } \\
\text { of inhabitants in the region. } \\
\text { Calculations are made using data } \\
\text { from Population on } 1 \text { January by } \\
\text { broad age group, sex and NUTS } 3 \\
\text { region (demo_r_pjanagrr3). }\end{array}$ & $\%$ & $\mathrm{X}$ & $\mathrm{X}$ & $\mathrm{X}$ & \\
\hline INOV & $\begin{array}{l}\text { Patents per million inhabitants. } \\
\text { Data retrieved from Patent } \\
\text { applications to the EPO by } \\
\text { priority year by NUTS } 3 \text { regions } \\
\text { (pat_ep_rtot). }\end{array}$ & $\begin{array}{l}\text { Number } \\
\text { of patents } \\
\text { per } \\
\text { million } \\
\text { inhabi- } \\
\text { tants }\end{array}$ & $\mathrm{X}$ & $\mathrm{X}$ & & $\mathrm{X}$ \\
\hline AEMPL & $\begin{array}{l}\text { Employment in the agriculture } \\
\text { sector. Calculated as the } \\
\text { proportion of workers employed } \\
\text { in agriculture, forestry and } \\
\text { fishing (A in NACE activities). } \\
\text { Data retrieved from Employment } \\
\text { (thousand persons) by NUTS } 3 \\
\text { regions (nama_10r_3empers). }\end{array}$ & $\%$ & $\mathrm{X}$ & $\mathrm{X}$ & & $\mathrm{X}$ \\
\hline IEMPL & $\begin{array}{l}\text { Employment in the industry } \\
\text { sector. Calculated as the } \\
\text { proportion of workers employed } \\
\text { in industry (except construction, } \\
\text { B-E in NACE activities). Data } \\
\text { retrieved from Employment } \\
\text { (thousand persons) by NUTS } 3 \\
\text { regions (nama_10r_3empers). }\end{array}$ & $\%$ & $\mathrm{X}$ & $\mathrm{X}$ & & $\mathrm{X}$ \\
\hline AGVA & $\begin{array}{l}\text { Agriculture gross value added. } \\
\text { Calculated as the proportion } \\
\text { of GVA created in agriculture, } \\
\text { forestry and fishing (A in } \\
\text { NACE activities). Data retrieved } \\
\text { from Gross value added at } \\
\text { basic prices by NUTS } 3 \text { regions } \\
\text { (nama_10r_3gva). }\end{array}$ & $\%$ & $\mathrm{X}$ & $\mathrm{X}$ & $\mathrm{X}$ & \\
\hline
\end{tabular}


End of Table A2

\begin{tabular}{|c|c|c|c|c|c|c|}
\hline \multirow{2}{*}{$\begin{array}{l}\text { Short } \\
\text { name }\end{array}$} & \multirow{2}{*}{$\begin{array}{l}\text { Full name, description and } \\
\text { source of data }\end{array}$} & \multirow{2}{*}{$\begin{array}{l}\text { Measure- } \\
\text { ment unit }\end{array}$} & \multicolumn{2}{|c|}{$\begin{array}{l}\text { NUTS level at which } \\
\text { data is available }\end{array}$} & \multicolumn{2}{|c|}{$\begin{array}{l}\text { Model for which } \\
\text { variable is used }\end{array}$} \\
\hline & & & 2 & 3 & GDP & GVA \\
\hline IGVA & $\begin{array}{l}\text { Industry gross value added. } \\
\text { Calculated as the proportion } \\
\text { of GVA created in industry } \\
\text { (except construction, B-E in } \\
\text { NACE activities). Data retrieved } \\
\text { from Gross value added at } \\
\text { basic prices by NUTS } 3 \text { regions } \\
\text { (nama_10r_3gva). }\end{array}$ & $\%$ & $\mathrm{X}$ & X & $\mathrm{X}$ & \\
\hline
\end{tabular}

Table A3. Analysis of overfunding

\begin{tabular}{|c|c|c|c|}
\hline $\begin{array}{l}\text { Dis- } \\
\text { aggre- } \\
\text { gation } \\
\text { level }\end{array}$ & $\begin{array}{l}\text { Estimated turning } \\
\text { point of positive } \\
\text { marginal effect on } \\
\text { convergence }\end{array}$ & $\begin{array}{l}\text { Regions that were overfunded, their actual funding } \\
\text { intensity and the country }\end{array}$ & $\begin{array}{l}\text { Amount of } \\
\text { overfunding }\end{array}$ \\
\hline \multicolumn{4}{|c|}{ Programming period of $2000-2006$} \\
\hline \multirow[t]{2}{*}{ NUTS 2} & $\begin{array}{l}1.08 \% \text { for } \\
\text { convergence } \\
\text { according to GDP }\end{array}$ & $\begin{array}{l}\text { Notio Aigaio-1.17-(EL); Norte-1.25-(PT); Algarve- } \\
\text { 1.37-(PT); Anatoliki Makedonia, Thraki-1.41-(EL); } \\
\text { Extremadura-1.42-(ES); Dytiki Ellada-1.42-(EL); } \\
\text { Centro-1.43-(PT); Ionia Nisia-1.44-(EL); Sterea } \\
\text { Ellada-1.55-(EL); Dytiki Makedonia-1.72-(EL); } \\
\text { Alentejo-1.99-(PT); Voreio Aigaio-2.04-(EL); Região } \\
\text { Autónoma da Madeira-2.26-(PT); Região Autónoma } \\
\text { dos Açores-2.74-(PT); Ipeiros-2.92-(EL) }\end{array}$ & $\begin{array}{l}6.967 \text { Bill. } \\
\text { EUR }\end{array}$ \\
\hline & $\begin{array}{l}2.69 \% \text { for } \\
\text { convergence } \\
\text { according to GVA }\end{array}$ & $\begin{array}{l}\text { Região Autónoma dos Açores-2.74-(PT); Ipeiros- } \\
\text { 2.92-(EL) }\end{array}$ & 116 Mill EUR \\
\hline \multirow[t]{2}{*}{ NUTS 3} & $\begin{array}{l}5.95 \% \text { for } \\
\text { convergence } \\
\text { according to GDP }\end{array}$ & Alto Tâmega-8.27-(PT); La Palma-8.44-(ES) & 507 Mill EUR \\
\hline & $\begin{array}{l}3.99 \% \text { for } \\
\text { convergence } \\
\text { according to GVA }\end{array}$ & $\begin{array}{l}\text { Terras de Trás-os-Montes-4.32-(PT); Alto Tâmega- } \\
\text { 8.27-(PT); La Palma-8.44-(ES) }\end{array}$ & 960 Mill EUR \\
\hline \multicolumn{4}{|c|}{ Programming period of 2007-2013 } \\
\hline NUTS 2 & $\begin{array}{l}2.20 \% \text { for } \\
\text { convergence } \\
\text { according to GDP }\end{array}$ & $\begin{array}{l}\text { Lubelskie-2.26-(PL); Dytiki Ellada-2.29-(EL); } \\
\text { Közép-Dunántúl-2.62-(HU); Nyugat-Dunántúl- } \\
\text { 2.68-(HU); Warminsko-Mazurskie-2.90-(PL); } \\
\text { Podkarpackie-2.95-(PL); Dél-Dunántúl-3.10-(HU); } \\
\text { Észak-Magyarország-3.40-(HU); Região Autónoma } \\
\text { dos Açores (PT)-3.42-(PT); Dél-Alföld-4.46-(HU); } \\
\text { Észak-Alföld-4.66-(HU) }\end{array}$ & 7.337 Bill EUR \\
\hline
\end{tabular}


End of Table A3

\begin{tabular}{|c|c|c|c|}
\hline \multirow[t]{2}{*}{$\begin{array}{l}\text { Dis- } \\
\text { aggre- } \\
\text { gation } \\
\text { level }\end{array}$} & $\begin{array}{l}\text { Estimated turning } \\
\text { point of positive } \\
\text { marginal effect on } \\
\text { convergence }\end{array}$ & $\begin{array}{l}\text { Regions that were overfunded, their actual funding } \\
\text { intensity and the country }\end{array}$ & $\begin{array}{l}\text { Amount of } \\
\text { overfunding }\end{array}$ \\
\hline & $\begin{array}{l}1.84 \% \text { for } \\
\text { convergence } \\
\text { according to GVA }\end{array}$ & $\begin{array}{l}\text { Jihozápad-1.85-(CZ); Severozapaden-1.88-(BG); } \\
\text { Strední Morava-1.92-(CZ); Eesti-1.93-(EE); Lietuva- } \\
\text { 1.97-(LT); Ipeiros-1.98-(EL); Latvija-2.01-(LV); } \\
\text { Yuzhen tsentralen-2.01-(BG); Podlaskie-2.02-(PL); } \\
\text { Alentejo-2.07-(PT); Swietokrzyskie-2.08-(PL); } \\
\text { Yugoiztochen-2.10-(BG); Lubelskie-2.26-(PL); } \\
\text { Dytiki Ellada-2.29-(EL); Közép-Dunántúl-2.62- } \\
\text { (HU); Nyugat-Dunántúl-2.68-(HU); Warminsko- } \\
\text { Mazurskie-2.90-(PL); Podkarpackie-2.95-(PL); } \\
\text { Dél-Dunántúl-3.10-(HU); Észak-Magyarország- } \\
\text { 3.40-(HU); Região Autónoma dos Açores (PT)- } \\
\text { 3.42-(PT); Dél-Alföld-4.46-(HU); Észak-Alföld- } \\
\text { 4.66-(HU) }\end{array}$ & $\begin{array}{l}11.940 \text { Bill } \\
\text { EUR }\end{array}$ \\
\hline \multirow[t]{2}{*}{ NUTS 3} & $\begin{array}{l}3.07 \% \text { for } \\
\text { convergence } \\
\text { according to GDP }\end{array}$ & $\begin{array}{l}\text { Gozo and Comino / Ghawdex u Kemmuna-3.11- } \\
\text { (MT); Tarnowski-3.12-(PL); Inowroclawski-3.21- } \\
\text { (PL); Zemgale-3.34-(LV); Bács-Kiskun-3.35- } \\
\text { (HU); Kesk-Eesti-3.36-(EE); Slupski-3.41-(PL); } \\
\text { Aitoloakarnania-3.42-(EL); Kyustendil-3.42-(BG); } \\
\text { Região Autónoma dos Açores (PT)-3.42-(PT); } \\
\text { Somogy-3.44-(HU); Pomurska-3.44-(SI); Baranya- } \\
\text { 3.48-(HU); Hajdú-Bihar-3.51-(HU); Elblaski- } \\
\text { 3.52-(PL); Borsod-Abaúj-Zemplén-3.55-(HU); } \\
\text { Sliven-3.56-(BG); Baixo Alentejo-3.57-(PT); } \\
\text { Vidzeme-3.58-(LV); Kurzeme-3.59-(LV); Veszprém- } \\
\text { 3.61-(HU); Nógrád-3.62-(HU); Tauragés apskritis- } \\
\text { 3.67-(LT); Sieradzki-3.80-(PL); Latgale-4.08-(LV); } \\
\text { Terras de Trás-os-Montes-4.11-(PT); Yambol-4.29- } \\
\text { (BG); Rzeszowski-4.30-(PL); Haskovo-4.40-(BG); } \\
\text { Békés-4.42-(HU); Jász-Nagykun-Szolnok-4.97- } \\
\text { (HU); Csongrád-5.79-(HU); Alto Alentejo-5.82- } \\
\text { (PT); Szabolcs-Szatmár-Bereg-5.92-(HU); Ithaki, } \\
\text { Kefallinia-7.30-(EL); Alto Tâmega-7.52-(PT); } \\
\text { Thesprotia-8.81-(EL). }\end{array}$ & 5.801 Bill EUR \\
\hline & $\begin{array}{l}3.62 \% \text { for } \\
\text { convergence } \\
\text { according to GVA }\end{array}$ & $\begin{array}{l}\text { Tauragės apskritis-3.67-(LT); Sieradzki-3.80-(PL); } \\
\text { Latgale-4.08-(LV); Terras de Trás-os-Montes- } \\
\text { 4.11-(PT); Yambol-4.29-(BG); Rzeszowski-4.30- } \\
\text { (PL); Haskovo-4.40-(BG); Békés-4.42-(HU); } \\
\text { Jász-Nagykun-Szolnok-4.97-(HU); Csongrád-5.79- } \\
\text { (HU); Alto Alentejo-5.82-(PT); Szabolcs-Szatmár- } \\
\text { Bereg-5.92-(HU); Ithaki, Kefallinia-7.30-(EL); Alto } \\
\text { Tâmega-7.52-(PT); Thesprotia-8.81-(EL). }\end{array}$ & 3.108 Bill EUR \\
\hline
\end{tabular}

